\title{
Production, Purification and Quality Testing of Pectinase Enzyme from Bacillus subtilis Isolated from Orange Peel
}

\author{
${ }^{* 1}$ Akshitha Babburi, ${ }^{2}$ Amita Kashyap, ${ }^{3}$ Sheyas Patel, ${ }^{4}$ Balakrishna \\ ${ }^{* 1}$ Illinos Institute of Technology, Chicago, Illinois \\ ababburi@,hawk.iit.edu \\ ${ }^{2}$ Rayalaseema University, Kurnool, India \\ ${ }^{3}$ Graphic Era, (Deemed to be University), Dehradun, Uttarakhand, India \\ ${ }^{4}$ Kakatiya University, Warangal, Telangana, India
}

Received: 20 ${ }^{\text {th }}$ December 2021, Accepted: $5^{\text {th }}$ February 2022, Published: $28^{\text {th }}$ February 2022

\begin{abstract}
Microorganisms as bioreactors have gained immense applicability both industrially and therapeutically. Natural ability of microbes in synthesizing some medicinally and industrially important compounds makes them the target of choice in research. Current work aims to utilize the ability of microbes to produce the enzyme pectinase in lab scale followed by its testing in the industrial application. Pectinase is a natural microbial enzyme that can hydrolyze the substrate pectin, a cell wall component of fruits and vegetables. The enzyme is industrially applied to soften the cell wall layer of the vegetables and fruits thereby causing high yield and efficacy in juice extraction. Study included the isolation of enzyme producing bacteria from spoiled orange peel as a source. Positive bacterial cultures capable of producing the enzyme are to be used in the production of enzyme followed by its purification using several downstream processing steps. Further, identification of the enzyme producing bacteria can be carried out based on grams staining and biochemical tests based on Beregy's manual.
\end{abstract}

Key Words: Pectin, Bioreactors, Downstream processing, Salt Precipitation, Dialysis, Immobilization

\section{Introduction}

Pectin is the outermost layer of the vegetable and fruit material that imparts a rigidity and tough nature to the cell wall. This pectin protects the food from spoilage and microbial infection. However in case of juice extraction and utilization of the food, this pectin layer acts as a hindrance and decreases the product output. Thus dissolving this layer becomes a task. Pectinases are the natural microbial enzymes that solve the purpose hereby making the cell wall delicate.

Pectinases are a group of enzymes under the term pectic enzymes which include pectolyaze, pectozyme and pectinase. Pectinases form one of the important enzymes highly studies and commercially used hydrolytic enzymes. These enzymes commonly solve the purposes of degrading plant tissues which enhances juice extraction from fruits like apples, sapota etc. These enzymes have been used in industrial wine production since 1960s. It helps brewing in two steps, 1st s by digesting the plant material efficiently enhancing the full flavors to be collected an secondly it clears the cloudiness in the final wine product thereby increasing its efficacy and look. Optimum temperature and $\mathrm{pH}$ at which they are most active are 45 to $55^{\circ} \mathrm{C}$ and work well at a $\mathrm{pH}$ of 4.5 to 5.5 .

Other industrial applications of pectinases include degumming of plant fibers, Textile processing and bioscouring of plant fiber, retting of plant fibers etc.

\section{Materials and Methods}

Sample Collection: The sample used for the isolation of desired microbial cells was orange peel. The peel was collected from a fruit market dump near Dilsukhnagar, Hyderabad. The sample is checked for minute spoilage 
which can confirm the presence of the microbial cells. Sample collected was sealed in a ziplock cover and brought to the laboratory for further processing.

Isolation of Microbes from the sample: The initial isolation of the microbes was carried out on Nutrient agar media. Three NAM plates were prepared and subjected for inoculation by rubbing with the orange peel under sterile laminar airflow conditions. The plates were incubated in an inverted position in incubator at $37^{\circ} \mathrm{C}$ overnight. After incubation plates were observed for the growth colonies.

Screening for the identification of pectinase positive bacteria: From the master plate of NAM (Peptone: $0.5 \%$, $\mathrm{NaCl}: 0.5 \%$, Yeast Extract: $0.2 \%$, Agar-agar: $1.5 \%, \mathrm{pH}: 7)$ the pectinase producers needs to be identified and isolated. For that a specialized media called Pectinase Screening Media is used. This media can specifically allow the growth of only pectinase producers. The media s prepared and 3 plates were made ready for streaking. Some of the randomly selected cultures from the NAM plates were streaked onto the Screening media plates under laminar air flow conditions. All the streaked plates were incubated overnight at $37^{\circ} \mathrm{C}$ for bacterial growth.

All the bacteria which are capable of releasing the pectinase enzyme produce visible colonies on the screening media plates. These cultures can further be used for enzyme production.

\section{Composition of pectinase screening media for 1 plate $(25 \mathrm{ml})$}

Sodium nitrate: $0.05 \mathrm{gm}$

Potassium chloride: $0.012 \mathrm{gm}$

Magnesium sulphate : $0.025 \mathrm{gm}$

Dipotassium phosphate: $025 \mathrm{gm}$

Trypton: $0.0125 \mathrm{gm}$

Agar: $0.7 \mathrm{gm}$

Pectin: $0.25 \mathrm{gm}$

Water: $25 \mathrm{ml}$

Pure culture preparation of positive colonies: Once the screening media was inoculated and incubated the results are very vital in the selection of the cultures and application for enzyme production. All the colonies that show positive result for pectin digestion in then screening media are selected and are subjected for pure culture preparation. NAM can be used as a standard media for pure cultures. NAM is prepared sterilized and plates are made under laminar airflow conditions. Positive colonies are selected and subjected for streak plate method to obtain pure cultures which can be further used for enzyme production and identification. After inoculation, plates were incubated at $37^{\circ} \mathrm{C}$ for $24 \mathrm{hrs}$.

Enzyme Production using specialized production media: Using the colonies selected in the screening step and the pure cultures of the respective colonies production media can be inoculated. Production media is a specialized liquid broth that contains chemicals useful for the bacterial growth and division. Additionally it contains high concentration of substrate specific for the enzyme being produced. Composition of Pectinase production media is specified below. The composition varies not only with the enzyme to be produced but also with the organism that is used to produce the enzyme. The below composition is suitable for pectinase enzyme production using bacteria as a bioreactor. Submerged liquid fermentation is used for enzyme production. The media after inoculation is subjected for incubation at $37^{\circ} \mathrm{C}$ for 7 to 10 days.

\section{Production media composition for Pectinase}

$\mathrm{NaNO}_{3}: 2.0 \mathrm{~g} / \mathrm{l}$

$\mathrm{KCl}: 0.50 \mathrm{~g} / 1$

$\mathrm{KH}_{2} \mathrm{PO}_{4}: 1.0 \mathrm{~g} / 1$

$\mathrm{MgSO}_{4} \cdot 7 \mathrm{H}_{2} \mathrm{O}: 0.50 \mathrm{~g} / \mathrm{l}$ 
Yeast extract: $1.0 \mathrm{~g} / 1$

Pectin powder: $5.0 \mathrm{~g} / 1$

Downstream Processing: Once the enzyme is produced in the production media after required incubation time, it becomes a vital step to separate it from the media and subject for purification. Purification involves a series of steps. The inoculated media is subjected for centrifugation at 8,000 rpm for $15 \mathrm{~min}$ to separate the solid media components and cells from the liquid supernatant. The supernatant is collected and subjected for salt precipitation with ammonium sulphate to precipitate the protein. The precipitated protein salt is further centrifuged and precipitated protein is dissolved in phosphate buffer. The buffered protein is now packed into a dialysis membrane and subjected for final purification in dialysis. The enzyme is obtained in pure form and studied for its quality and activity.

Quality assay of enzyme based on industrial application: The enzyme pectinase is known to have immense applications in leather and food industry. The current work involves the identification of enzyme quality based on its application in fruit juice extraction. Apples were used for juice extraction and enzyme quality determination. Equal weight (25gms) of apple was taken in two different motor pestles and was washed and cut into small pieces. In one of the sample $0.5 \mathrm{ml}$ of water was added and in the test sample $0.5 \mathrm{ml}$ of extracted and purified enzyme was added. The samples were smashed and homogenized into smooth slurry. The smashed sample is subjected for filtration using muslin cloth or filter paper. The juice collected from both the samples needs to be measured and compared to check the efficacy of the enzyme thus produced.

Identification of bacteria based on Biochemical tests: The pure culture that was positive for enzyme production needs to be identified in the procedure. Identification of bacteria mainly requires gram staining followed by biochemical tests based on Bergey's manual. These biochemical tests include a series of tests conducted one after the other based on the characteristics of bacteria. Initially Grams staining is performed which is followed by the biochemical tests.

\section{Results and Discussion}

Once the bacterial colonies were cultured on the NAM plate from the sample, these colonies were subjected for screening test on pectinase screening agar media. The colonies which gave positive result were selected for further study.

Table 1: Biochemical tests Result for the identification of bacteria

\begin{tabular}{lll}
\hline S.No & Biochemical Test & Result \\
\hline 1 & Indole Production & - \\
2 & Citrate Utilization & + \\
3 & Methyl Red & - \\
4 & Voges Proskauer & + \\
5 & Oxidase & + \\
6 & Catalase & + \\
7 & Starch Hydrolysis & + \\
8 & Nitrate Reductin & + \\
9 & Casein Hydrolysis & + \\
10 & Gas production from Glucose & - \\
\hline
\end{tabular}

Qualitative assay based on Enzyme Application in fruit juice extraction 
The figure 1 shows the difference between the volume of apple juice extracted with the use of enzyme and without the use of enzyme. It was observed that $2 \mathrm{gms}$ of apple yielded $7 \mathrm{ml}$ of juice in the presence of enzyme and only $4 \mathrm{ml}$ of juice without he enzyme. Thus the application of enzyme is an efficient step for maximum yield.

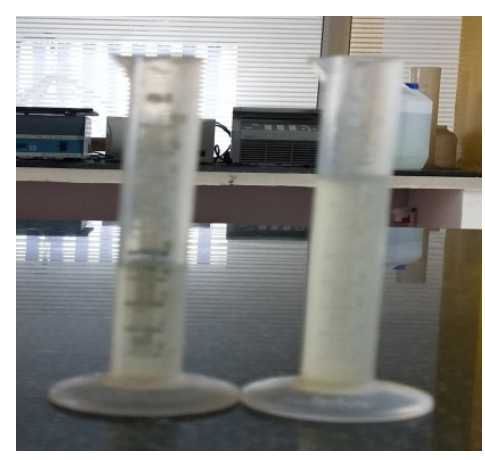

Fig 1: Comparison of fruit juice extracted from apple with and without the use of enzyme

\section{Conclusion}

The current work aims to produce Pectinase enzyme in lab scale using bacteria. The required positive bacteria are obtained from orange peel which was used as a source. Pectinase screening media is used as a reference to obtain only the pectinase producers for the work. Isolated pectinase positive cultures are subjected for pure culturing in NAM. The culture is later used to inoculate the production media and kept for 6 days incubation to obtain enzyme. Once the enzyme is obtained it is subjected for various purification steps through downstream processing. The final pure enzyme is subjected for quality determination by using it for fruit juice extraction. Apple sample was used for juice extraction. Juice was extracted from 2 equal halves of one with enzyme and other with water as control. The results revealed that the volume of juice obtained in enzyme tube was higher than control. This proves the quality of enzyme and its applicability for industrial purpose. Further the bacteria which produced the enzyme were subjected for several biochemical tests for its identification based on Bergeys manual. The culture was identified to be Bacillus subtilis.

\section{References}

1. A. Thakur, R. Pahwa, S. Singh, and R. Gupta, "Production, purification, and characterization of polygalacturonase from Mucor circinelloides ITCC 6025," Enzyme Research, vol. 2010, Article ID 170549, 7 pages, 2010

2. Kashyap, A., Gunjan, V. K., Kumar, A., Shaik, F., \& Rao, A. A. (2016). Computational and clinical approach in lung cancer detection and analysis. Procedia Computer Science, 89, 528-533.

3. Javed, R.; Nawaz, A.; Munir, M.; Hanif, M.; Mukhtar, H.; Haq, I.U.; Abdullah, R. Extraction, purification and industrial applications of pectinase: A review.J.Biotechnol.Biores.2018,1,1-6

4. Shaik, F., Sharma, A. K., Ahmed, S. M., Gunjan, V. K., \& Naik, C. (2016). An improved model for analysis of Diabetic Retinopathy related imagery. Indian J Sci Technol, 9, 44.

5. Gunjan, V. K., Shaik, F., Kashyap, A., \& Kumar, A. (2017). An interactive computer aided system for detection and analysis of pulmonary TB. Helix J, 7(5), 2129-2132.

6. Tariq A, Latif $Z$. Isolation and biochemical characterization of bacterial isolates producing different levels of polygalacturonases from various sources. African Journal of Microbiology Research. 2012;6(45):725964

7. Venkatanaga-Raju, E. and Divakar, G., 2013. Production of pectinase by using bacillus circulansisolated from dump yards of vegetable wastes, Int. J. Pharmaceut. Sci. Res., 4: 2615-2622 